RESEARCH PAPER

\title{
THE COMPETENCES OF HR MANAGERS AND THEIR IMPACT ON THE ORGANIZATIONAL SUCCESS OF MNCS' SUBSIDIARIES IN THE CEE REGION
}

\author{
Poór, J., Slavić, A., Berber, N.
}

\begin{abstract}
Multinational companies that have settled in Central and Eastern Europe (CEE) significantly contribute to the recognition of modern HRM concepts and implementation of the relevant HRM practices in the region (Lewis, 2005). To be a strategic partner, HRM managers have to possess various professional and personal competences (Orme, 2010). The aim of this paper is to analyze the main competences of HR managers and their impact on companies' performances. The research hypothesis, based on 2012-2013 CEEIRT data, is that there is a statistically significant relationship among the HR managers' competences and the performances of the MNCs' subsidiaries in Hungary, Poland, Romania, Serbia and Slovakia. The analyzed HR competences are: business knowledge, strategic contribution, personal credibility, HR services, HR information system and foreign language competences. The research analyzed the following organizational performances: profitability, service quality, rate of innovations and environmental matters.
\end{abstract}

Keywords: HRM; HRM competences; multinational enterprises; Central and Eastern Europe JEL classification: F23, M12, J24, L21

\section{Introduction}

Multinational companies are often seen as being carriers of globalization, spreading managerial knowledge and techniques internationally through the dissemination of , best practice" (Festing, 2012). Kirca et al. (2011) claim that multinationality provides the most efficient governance structure for transferring the valuable, rare, inimitable, nonsubstitutable resources of a company (technological know-how, management and marketing skills) across country borders within a firm and that these transfers have positive impacts on firms' profitability. Ferner, Edwards and Tempel (2011) emphasize that MNCs are complex organizations, marked by the dispersion of power among groups, functions and operating units.

The subsidiaries of MNCs operate under conditions of 'institutional duality', facing both the institutional terrain of the international firm itself and that of the host environment in which they operate. These institutional spheres exert rival isomorphic pressures that come to the forefront when practices are transferred from the parent to host operations. Crucially, MNCs may use power to shape macro-level institutions, affecting the processes whereby they are established, maintained over time, revised in function or scope, or replaced by other arrangements. Erdős (2003) considers that foreign companies 
with high capital value have an important influence on the smaller countries' growth potential, while Stiglitz (2003) calls attention to their disadvantages, highlighting that these big companies often negatively impact the operations of small local companies.

Today, successful organizations need to address their human resources much more in order to achieve their goals and to acquire a competitive advantage in a turbulent environment (Zareei, Zamani and Tanaomi, 2014, p. 4). Jiang et al. (2012) recall that researchers in strategic HRM have categorized organizational outcomes into three primary groups related to HRM. HR outcomes refer to those most directly related to HRM in an organization, such as employee skills and abilities, employee attitudes, behaviors, and turnover. Operational outcomes are those related to the goals of an organizational operation, including productivity, product quality, quality of service, and innovation. Financial outcomes reflect the fulfilment of the economic goals of organizations. Typical financial outcomes include sales growth, return on invested capital, and return on assets. HR practices are falling into one of three primary dimensions: skill-enhancing HR practices (comprehensive recruitment, rigorous selection, and extensive training), motivation-enhancing HR practices (performance management, competitive compensation, incentives and rewards, extensive benefits, promotion and career development, and job security) and opportunity-enhancing HR practices (flexible job design, work teams, employee involvement). The meta-analysis proved that there is a direct relationship between skill-enhancing HR practices and motivation-enhancing HR practices and financial outcomes, i.e. HRM can improve organizational effectiveness.

Generally in the CEE region, MNCs' subsidiaries have the most developed HRM practices and HR managers often have a business partner role there. To be a successful strategic partner of their organizations, HRM managers nowadays have to possess various professional and personal competences. Competency refers to the knowledge, skills, capabilities or personal characteristics of an individual that directly affect his/her job performance (Brockbank and Ulrich, 2003). For HRM practitioners and researchers, it is important to know a lot about the impact of MNCs on HRM practices in the CEE region and to identify the main HRM competences and their impact on the company's outcomes.

Ulrich, Brockbank, Yeung and Lake (1995) note that HRM competences fall into three domains: knowledge of business, HRM functional expertise and management of change. According to Long, Wan Ismail and Amin (2013) there are several vital competencies including business knowledge, culture management, effective relationship and human resource development skills. A similar but more detailed list of HR competencies was developed by Zareei, Zamani and Tanaomi (2014) who emphasized strategic management, business knowledge, management of talent, employee relation, quality of work-family life, and information technology. Other authors (Brockbank, Ulrich, Younger, and Ulrich, 2012) have proposed the next most important HR competencies for HR managers in the contemporary turbulent environment. These are: credible activist, strategic positioner, capability builder, change champion, HR innovator and integrator, and technology proponent. Some very interesting research has been performed in Slovenia, a CEE country, where Kohont and Brewster (2014) found that the "complexity of HR managers' roles, and expectations of their competencies, increases with an increasing level of internationalization of companies. Orientation to people and conflict resolution are seen as elementary competencies needed in all stages of internationalization. The key competence is seen to be strategic thinking that, according to CEOs and expatriates, goes hand in hand with cultural sensitivity (Briscoe and 
Shuler, 2004), openness to change and a comprehensive understanding of the international environment and business processes". Šparl et al. (2013) analyzed the influence of managerial competencies on business success in Austrian and Slovenian firms. They found that in a growing and motivating environment, even in times of crisis, strategic competency management focusing on leadership competencies will help to improve corporate performance. These results are found for the sample of Austrian firms, but not for Slovenian.

The aim of this paper is to explore the main competences of the HRM managers and their impact on the companies' outcomes in the CEE region. The relationship among main HRM competences and companies' outcomes in Hungary, Poland, Romania, Serbia and Slovakia will be analyzed based on CEEIRT research from 2012-2013. The research hypothesis is that there is a statistically significant relationship among the competences of HRM managers and the performances of the MNCs' local subsidiaries in the CEE region. The analyzed competences of HR managers are: business knowledge, strategic contribution, personal credibility, HR services, HR information system and foreign language competences. The research focused on the following organizational performances: profitability, service quality, rate of innovations and environmental matters.

\section{Methods}

The international CEEIRT (Central and Eastern European International Research Team) research model has been developed over the past few years (Poór and Farkas 2012) and now we take into consideration additional internal factors (company characteristics, phases in company development, mandates, etc.).

Figure 1 | Research model

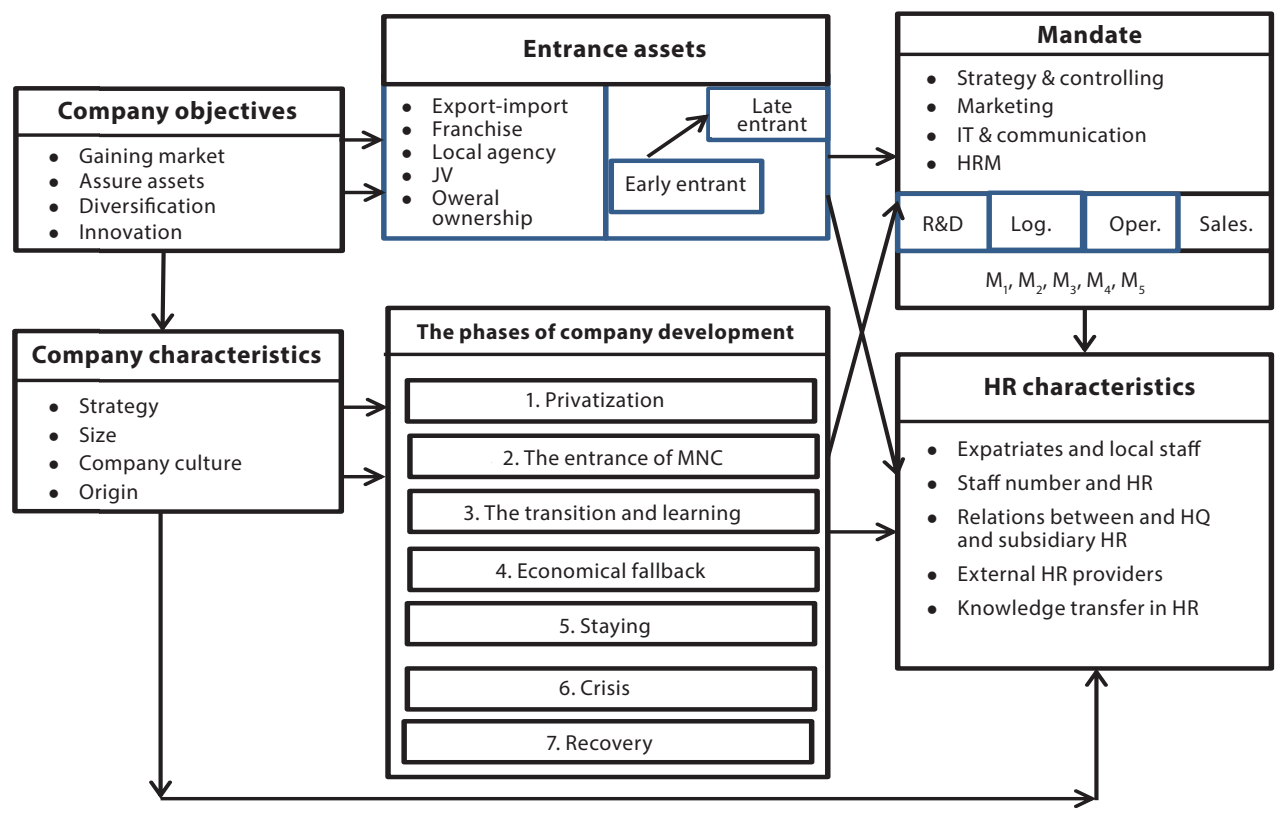

Source: Based on authors' own research 
To obtain data on the MNCs' subsidiaries' HRM practices in the CEE region, standardized questionnaires (translated to the official languages of examined countries) were used. The on-line questionnaire was filled out by the person responsible for HR practices in each MNC subsidiary (HR director, HR expert, CEO, etc.). The data analysis was done by SPPS Version 21, using descriptive statistics and Spearman's Correlation Test.

The current analysis was made on the sample of five CEE countries: Hungary, Slovakia, Serbia, Poland and Romania. The total number of organizations included into the analysis is 254 .

Table 1 | Sample of countries participating in the CEEIRT survey 2012/2013

\begin{tabular}{|l|c|c|}
\hline Country & Frequency & Percent \\
\hline Hungary & 118 & 46,5 \\
\hline Poland & 53 & 20,9 \\
\hline Romania & 34 & 13,4 \\
\hline Serbia & 19 & 7,5 \\
\hline Slovakia & 30 & 11,8 \\
\hline Total & 254 & 100,0 \\
\hline
\end{tabular}

Source: Authors' analysis based on CEEIRT data

From the data in Table 1, it is evident that the main part of the sample is made up of Hungarian organizations (46.5\%), while Serbian organizations make up the smallest part of the sample $(7.5 \%)$.

Regarding the main business area or sector of business, the majority of the sample is made of organizations from industry and production $(45.7 \%)$, then from business services $(19 \%)$, trade $(16.5 \%)$ and financial services $(13 \%)$.

Most of the MNC subsidiaries that participated in this research were founded before 1995 (28\%), then in the period between 1995 and $2000(26.4 \%)$ and then in the period until $2005(23 \%)$. About $21 \%$ of the analyzed subsidiaries were established after 2006 . According to CEEIRT data, $50 \%$ of the subsidiaries were established by mergers or acquisitions, while $49 \%$ of them were founded through green-field investments (new organization and investment).

Since the economic crisis starting in 2008 has affected most European economies, the research contained a question on how subsidiaries faced these challenges. Table 2 shows the key business strategies of the analyzed MNC subsidiaries' in 2012-2013. 
Table 2 | Distribution of the analyzed MNC subsidiaries by key business strategy

\begin{tabular}{|l|c|c|}
\hline Business strategies & Frequency & Percent \\
\hline Growth, market expansion & 149 & 58,7 \\
\hline Stability & 93 & 36,6 \\
\hline Cut-back, outsourcing & 8 & 3,1 \\
\hline Other & 2 &, 8 \\
\hline Total & 252 & 99,2 \\
\hline Missing & 2 &, 8 \\
\hline Total & 254 & 100,0 \\
\hline
\end{tabular}

Source: Authors' analysis based on CEEIRT data

Irrespective of the threats from the external the business environment, $59 \%$ of the analyzed organizations used the strategy of expansion aiming at growth and market expansion. Stability, as a business strategy alternative, was used by $36.6 \%$ of subsidiaries, while only $3 \%$ of them reacted to the economic crisis by downsizing their activities, using cut-back strategies and outsourcing.

\section{Results}

In the line with the research's aim - to analyze the relation between the competences of HR managers and organizations' business results - respondents were asked to indicate the level of their business results in 2012-2013 regarding profitability, service quality, innovation rate and environmental performances on the scale from 1 (poor) to 5 (superior).

Table 3 | The level of key business indicators in MNCs' subsidiaries in CEE ( $N=254)$

\begin{tabular}{|l|l|c|c|c|c|}
\hline \multicolumn{2}{|l|}{ Country } & Profitability & Service quality & $\begin{array}{c}\text { Rate of } \\
\text { innovation }\end{array}$ & $\begin{array}{c}\text { Environmental } \\
\text { matters }\end{array}$ \\
\hline \multirow{2}{*}{ Total } & Mean & 3,55 & 4,06 & 3,71 & 3,70 \\
\cline { 2 - 6 } & SD &, 909 &, 745 &, 919 &, 957 \\
\hline
\end{tabular}

Source: Authors' analysis based on CEEIRT data

According to the data from the table, it is obvious that MNCs' subsidiaries in the CEE region have experienced business success, as on the average, all performance measures are above 3.00 (indicating a level which is on the average equal to their competitors' performances). The MNCs best performances were determined regarding their service quality $(4,06)$ and rate of innovations $(3,71)$, their performances regarding environmental matters $(3,70)$ and then profitability $(3,55)$.

On the other hand, as the second important variable in the research, human resource competences were explored through the measurement of the importance of various HR 
competences for business success. Respondents were asked to indicate the importance of different HR competences from 1 (not important) to 4 (highly important).

Table 4 | The level of importance of HR competences in MNCs' subsidiaries in CEE ( $N=254)$

\begin{tabular}{|l|c|c|c|c|c|c|c|}
\hline \multicolumn{2}{|c|}{} & $\begin{array}{c}\text { Business } \\
\text { knowledge } \\
\text { Country }\end{array}$ & $\begin{array}{c}\text { Strategic } \\
\text { contribution } \\
\text { chain, value } \\
\text { creation) } \\
\text { (managing culture, } \\
\text { champio-ning } \\
\text { changes, strategic } \\
\text { decisions) }\end{array}$ & $\begin{array}{c}\text { Personal credi- } \\
\text { bility (achieving } \\
\text { results, effective } \\
\text { relationships, } \\
\text { communication } \\
\text { skills) }\end{array}$ & $\begin{array}{c}\text { HR } \\
\text { services } \\
\text { (staffing, } \\
\text { T\&D, PM, } \\
\text { etc.) }\end{array}$ & $\begin{array}{c}\text { Usage } \\
\text { of } \\
\text { HRIS }\end{array}$ & $\begin{array}{c}\text { Foreign } \\
\text { language } \\
\text { skills }\end{array}$ \\
\hline \multirow{2}{*}{ Total } & Mean & 2,88 & 2,91 & 3,30 & 3,06 & 2,67 & 3,13 \\
\cline { 2 - 8 } & SD &, 906 &, 914 &, 725 &, 884 &, 916 &, 842 \\
\hline
\end{tabular}

Source: Authors' analysis based on CEEIRT data

From the data in the table above, it is evident that MNC subsidiaries in the analyzed CEE countries emphasized personal credibility as the most important competence $(\mathrm{M}=3.30, \mathrm{SD}=0.725)$. Personal credibility implies several characteristics such as effective relationships and very good communication skills, achievement of results and organizational goals. The second most important HR competence was knowledge of a foreign language $(\mathrm{M}=3.13, \mathrm{SD}=0.842)$. This was expected to be an important competence because of the nature of MNCs' business. Large organizations usually do their business in different countries where it is important to balance between parent country, home country and even third country workers and their cultures, where the language is one of the most important elements for performing business. The third most important HR competence was professionalism in HRM activities $(\mathrm{M}=3.06, \mathrm{SD}=0.884)$ like recruitment and selection of employees, training and development, compensation, performance management. Usage of the human resource information system (HRIS) was rated as the least important HR competence $(\mathrm{M}=2.67, \mathrm{SD}=0.916)$ for organizations' success.

The last and the most interesting part of the analysis was dedicated to the exploration of the relationship between HR competences and business performances. According to the data in table 5, there are statistically significant correlations between the analyzed HR competences and business performance in the CEE region.

In the case of profitability as one of the most important performance measures, there are positive statistically significant correlations with the following HRM competences: business knowledge (Spearman's rho=0.140, $\mathrm{p}=0.03$ ), personal credibility (Spearman's rho $=0.172, \mathrm{p}=0.007$ ), and foreign language skills (Spearman's rho=0.153, $\mathrm{p}=0.017$ ). Regarding service quality as a performance measure, it has statistically significant relations with the following HRM competences: (Spearman's rho=0.203, $\mathrm{p}=0.001$ ), personal credibility (Spearman's rho $=0.255, \mathrm{p}=0.000$ ), several HR services (Spearman's $\mathrm{rho}=0.163, \mathrm{p}=0.011$ ), and foreign language skills (Spearman's rho=0.186, $\mathrm{p}=0.003$ ). Rate of innovation has statistically significant correlations with the following HRM competences: business knowledge (Spearman's rho=0.243, $\mathrm{p}=0.000$ ), strategic contribution (Spearman's rho $=0.177, \mathrm{p}=0.006$ ), personal credibility (Spearman's rho $=0.236$, $\mathrm{p}=0.000$ ), and foreign language skills (Spearman's rho $=0.199, \mathrm{p}=0.002$ ). One especially 
interesting part of the research was the analysis of correlations between environmental matters and HR competences. Positive statistically significant correlations have been found between environmental matters and each of the mentioned HR competences: business knowledge (Spearman's rho $=0.269, \mathrm{p}=0.000$ ), strategic contribution (Spearman's rho $=0.329, p=0.000)$, personal credibility (Spearman's rho $=0.275, p=0.000)$, HR services (Spearman's rho $=0.197, p=0.002$ ), the usage of HRIS (Spearman's rho $=0.165, p=0.011$ ), and foreign languages skills (Spearman's rho=0.246, $\mathrm{p}=0.000$ ).

Table 5 | Spearman's Correlation Test $(\mathrm{N}=\mathbf{2 5 4})$

\begin{tabular}{|l|l|c|c|c|c|c|c|}
\hline \multicolumn{2}{|l|}{} & $\begin{array}{c}\text { Business } \\
\text { know- } \\
\text { ledge }\end{array}$ & $\begin{array}{c}\text { Strategic } \\
\text { contri- } \\
\text { bution }\end{array}$ & $\begin{array}{c}\text { Personal } \\
\text { credi- } \\
\text { bility }\end{array}$ & $\begin{array}{c}\text { HR ser- } \\
\text { vices }\end{array}$ & $\begin{array}{c}\text { Usage of } \\
\text { HRIS }\end{array}$ & $\begin{array}{c}\text { Foreign } \\
\text { lang. } \\
\text { skills }\end{array}$ \\
\hline \multirow{2}{*}{$\begin{array}{l}\text { Profita- } \\
\text { bility }\end{array}$} & Spearman's rho &, $140^{*}$ &, 111 &, 111 &, $172^{* *}$ &, 099 &, $153^{*}$ \\
\cline { 2 - 8 } & Sig. (2-ailed) &, 030 &, 085 &, 084 &, 007 &, 125 &, 017 \\
\hline $\begin{array}{l}\text { Service } \\
\text { quality }\end{array}$ & Spearman's rho &, $203^{* *}$ &, 124 &, $255^{* *}$ &, $163^{*}$ &, 112 &, $186^{* *}$ \\
\cline { 2 - 8 } & Sig. (2-ailed) &, 001 &, 053 &, 000 &, 011 &, 082 &, 003 \\
\hline $\begin{array}{l}\text { Rate of } \\
\text { inno- } \\
\text { vation }\end{array}$ & Spearman's rho &, $243^{* *}$ &, $177^{* *}$ &, $236^{* *}$ &, 049 &, 101 &, $199^{* *}$ \\
\cline { 2 - 8 } & Sig. (2-ailed) &, 000 &, 006 &, 000 &, 444 &, 119 &, 002 \\
\hline $\begin{array}{l}\text { Environ- } \\
\text { mental } \\
\text { matters }\end{array}$ & Spearman's rho &, $269^{* *}$ &, $329^{* *}$ &, $275^{* *}$ &, $197^{* *}$ &, $165^{*}$ &, $246^{* *}$ \\
\cline { 2 - 9 } & Sig. (2-ailed) &, 000 &, 000 &, 000 &, 002 &, 011 &, 000 \\
\hline
\end{tabular}

Source: Authors' analysis based on CEEIRT data

In the case of profitability as one of the most important performance measures, there are positive statistically significant correlations with the following HRM competences: business knowledge (Spearman's $\mathrm{rho}=0.140, \mathrm{p}=0.03$ ), personal credibility (Spearman's rho $=0.172, \mathrm{p}=0.007)$, and foreign language skills (Spearman's rho $=0.153$, $\mathrm{p}=0.017$ ). Regarding service quality as a performance measure, it has statistically significant relations with the following HRM competences: (Spearman's rho=0.203, $p=0.001$ ), personal credibility (Spearman's rho $=0.255, \mathrm{p}=0.000$ ), several HR services (Spearman's rho $=0.163, p=0.011$ ), and foreign language skills (Spearman's rho=0.186, $p=0.003$ ). Rate of innovation has statistically significant correlations with the following HRM competences: business knowledge (Spearman's rho=0.243, $\mathrm{p}=0.000$ ), strategic contribution (Spearman's rho $=0.177, \mathrm{p}=0.006$ ), personal credibility (Spearman's rho $=0.236$, $\mathrm{p}=0.000$ ), and foreign language skills (Spearman's rho $=0.199, \mathrm{p}=0.002$ ). One especially interesting part of the research was the analysis of correlations between environmental matters and HR competences. Positive statistically significant correlations have been found between environmental matters and each of the mentioned HR competences: business knowledge (Spearman's rho $=0.269, \mathrm{p}=0.000$ ), strategic contribution (Spearman's rho $=0.329, \mathrm{p}=0.000$ ), personal credibility (Spearman's rho $=0.275, \mathrm{p}=0.000)$, HR services (Spearman's rho $=0.197, \mathrm{p}=0.002$ ), the usage of HRIS (Spearman's rho $=0.165, \mathrm{p}=0.011$ ), and foreign languages skills (Spearman's rho=0.246, $\mathrm{p}=0.000$ ). 


\section{Conclusion}

Multinational companies have a significant impact on the development of HRM practices in the CEE region. Applying the similar HR patterns as in the headquarters or other MNCs, they spread "best practices" in the ex-socialist countries concerning HRM activities, the role of HR managers in the strategic management process and the impact of HRM on organizational performances.

Based on the obtained CEEIRT data from Hungary, Poland, Romania, Serbia and Slovakia, the characteristics of MNC subsidiaries operating in the CEE region and their HR patterns can be recognized. The majority of them are in industry, trade and financial services. As an answer to the economic crisis that started in 2008, MNC subsidiaries' strategic goal is the growth of their business and market share. They rate their performances as above average and underline success concerning the quality of their services and the rate of innovations. In the subsidiaries of MNCs among the HRM competences, the most important are personal credibility, foreign language skills, HR services and strategic contribution. The ranking points out the nature of MNCs and their expectations from a HR manager.

The results of the correlation analysis prove that business knowledge and foreign language skills are very important HR competences since positive statistically significant correlations with all four performance measures are found. Beside these, the personal credibility of managers and different HR activities are also important for business outcomes. Only in the case of the usage of HRIS is there some evidence of correction only with environmental performances, but not with other performance measures.

In the case of profitability as an organizational outcome, the impact of HR services is the most powerful. The impact of the personal credibility of HR managers is the most important factor in reaching service quality. In the case of the rate of innovations, the business knowledge of HR professionals is necessary, while in the case of environmental matters the strategic contribution of HR mangers is the most forcible.

Beside the methodological limitations of CEEIRT research concerning the sample and representativeness of the obtained data, the paper gives valuable insight on the HRM competences and their effect on organizational performance at the local subsidiaries of MNCs in the CEE region.

\section{References}

Briscoe, D., Schuler, R. (2004). International Human Resource Management. London: Routledge.

Brockbank, W., Ulrich, D. (2003). Competencies for the New HR: Society for Human Resource Management. University of Michigan Business School: Global Consulting Alliance.

Brockbank, W., Ulrich, D., Younge, J., Ulrich, M. (2012). The Future is Now: HR Competencies for High Performance. Ave University: The RBL Group.

Erdős, T. (2003). Sustainable Economic Growth (In Hungarian). Budapest: Akadémiai Kiadó.

Ferner, A., Edwards, T., Tempel, A. (2012). Power, institutions and the cross-national transfer of employment practices in multinationals. Human Relations, 65(2): 163-187.

Festing, M. (2012). Strategic human resource management in Germany: evidence of convergence to the U.S. model, the European model, or a distinctive national model, Academy of Management Perspectives, 26 (2): 37-54. 
Jiang, K., Lepak, D. P., Hu, J., Baer, J. C. (2012). How does human resource management influence organizational outcomes? A meta-analytic investigation of mediating mechanisms. Academy of Management Journal, 55 (6): 1264-1294.

Kirca, A. H., Hult, G. T. M., Roth, K., Cavusgil, S. T., Perryy, M. Z., Akdeniz, M. B., White, R. C. (2011). Firm-specific assets, multinationality, and financial performance: A meta-analytic review and theoretical integration. Academy of Management Journal, 54 (1): 47-72.

Kohont, A., Brewster, C. (2014). The roles and competencies of HR managers in Slovenian multinational companies. Baltic Journal of Management, 9 (3): 294-313.

Lewis, P. C. (2005). How the East was won. New York: Palgrave Macmillan.

Long, C. S., Wan Ismail W. K., Mohd A. S. (2013). The role of change agent as mediator in the relationship between HR competencies and organizational performance. The International Journal of Human Resource Management, 24 (10): 2019-2033.

Orme, J. (2010). HR leader challenge in the future. In $11^{\text {th }}$ International Human Resource Management Conference "Delivering World Class Research to Achieve Global Results", Birmingham: Aston Business School, 9-13 June, 2010.

Poór, J., Farkas, F. (2012). Human Resource Management under Changes in Central and Eastern Europe, (In Hungarian), Gödöllö: Szent István Egyetemi Kiadó.

Šparl, P., Žnidaršič, A., Kasper, H., Mühlbacher, J., Kovač, J. (2013). Management Competencies and Organizational Performance in CEE: A Comparison of Slovenia and Austria. Organizacija, 46 (5): 214-220.

Stiglitz J. E. (2003). Globalization and its Negative Influences, (In Hungarian). Budapest: Nap Kiadó.

Ulrich, D., Brockbank, W., Yeung, A. K., Lake, D. G. (1995). Human resource competences: An empirical assessment. Human Resource Management, 34 (4): 473-495.

Zareei, E., Zamani, A., Tanaomi, M. (2014). A conceptual model of human resources competencies (HRC) using structural equation modelling: a case study. International Journal of Business Innovation and Research, 8 (1): 1-19.

\section{Authors}

József Poór, Ph.D.

Full Professor of Management, Szent István University Páter Károly u. 1, 2103 Gödöllő, Hungary

poorjf@t-online.hu

\section{Agneš Slavić, Ph.D.}

Assistant Professor, University of Novi Sad, Faculty of Economics, Subotica, Serbia Segedinski put 9-11, 24000 Subotica, Serbia

slavica@ef.uns.ac.rs

Nemanja Berber, MSc.

Research Assistant, University of Novi Sad, Faculty of Economics, Subotica, Serbia Segedinski put 9-11, 24000 Subotica, Serbia

berber@ef.uns.ac.rs

We would like to acknowledge the great efforts of the Central and Eastern European International Research Team (CEEIRT) members for their dedicated work on collecting and preparing data on HRM in MNCs subsidiaries in several countries of Central and Eastern Europe region, during the second round of CEEIRT research in 2012 and 2013. 